\title{
GENETICS OF HYPERURICAEMIA IN BLACKFEET AND PIMA INDIANS*
}

\author{
BY \\ WILLIAM M. O'BRIEN, $\uparrow$ THOMAS A. BURCH, AND THE LATE JOSEPH J. BUNIM \\ From the National Institute of Arthritis and Metabolic Diseases, Bethesda, Maryland.
}

It is generally agreed that hyperuricaemia is inherited, although the exact mechanism of inheritance is not well understood. In the late 1940s two papers appeared in which hyperuricaemia was studied as a simple monofactorial trait. In neither case did the data fit simple genetic models well. Smyth, Cotterman, and Freyberg (1948) concluded it to be inherited as a simple monofactorial dominant in which only a portion of the heterozygotes manifested the trait, while Stecher, Hersh, and Solomon (1949) concluded it to be dominant with varying penetrance in some families and recessive with varying penetrance in others. The metric character of the trait and the necessity of invoking penetrance casts doubt on the hypothesis of simple inheritance. Hauge and Harvald (1955) studied the uric acid levels in siblings of probands with gout. The uric acid of brothers was $1.0 \mathrm{mg}$. per cent. greater than controls, and of sisters $1.4 \mathrm{mg}$. per cent. greater than controls; the distribution of urate levels was normal, and the authors suggested the trait was polygenic.

The present study was undertaken to determine whether hyperuricaemia is, indeed, inherited, and, if so, what the mechanism of inheritance might be.

Two populations were studied: the Blackfeet Indians of Montana, and the Pima Indians of Arizona; 86 per cent. of all individuals of the designated tribe aged 30 and over living on the reservation were studied. All matings in the population and their offspring were identified; paternities in the Pima Indians were checked by multiple blood groups. Uric acid determinations were made in duplicate by the uricase spectrophotometric method of Liddle, Seegmiller, and Laster (1959). Height and weight were recorded and a history obtained. Each individual was carefully examined for joint disease, and

* Read at the 92nd Annual Meeting of the American Public Health

Association, New York, on October 8, 1964 . Present address: Department of Epidemiology and Public Health, Yale University, School of Medicine, New Haven, Connecticut.
$X$ rays of the hands, feet, and neck obtained. Postprandial blood sugars were obtained on the Pima Indians.

The uric acid values for the two populations are shown in Table I. In both the uric acid levels were normally distributed, the mean being 4.89 in Blackfeet and 4.22 in the Pimas. If we define hyperuricaemia as a serum uric acid concentration equal to or greater than $6 \mathrm{mg}$. per cent. in females and $7 \mathrm{mg}$. per cent. in males (Kellgren, 1962), then 7 per cent. of the Blackfeet and about 3 per cent. of the Pimas had hyperuricaemia. Of 31 Pimas with hyperuricaemia, two had definite gout and fourteen had mono- or polyarthritis compatible with gout and without signs diagnostic of other rheumatic diseases. Of 73 Blackfeet with hyperuricaemia, twelve had possible gout.

TABLE I

CHARACTERISTICS OF THE POPULATIONS

\begin{tabular}{l|c|c|c|c|c|c}
\hline \multicolumn{1}{c|}{ Tribe } & $\begin{array}{c}\text { Number } \\
\text { of } \\
\text { Persons }\end{array}$ & \multicolumn{2}{c|}{ Uric Acid } & $\begin{array}{c}\text { \% with } \\
\text { Hyper- }\end{array}$ & \multicolumn{2}{c|}{ Cases of Gout } \\
Blackfeet & 1,018 & $4 \cdot 89 \pm$ & $1 \cdot 19$ & $7 \cdot 17$ & 0 & 12 \\
Pima & 949 & $4 \cdot 22 \pm$ & $1 \cdot 19$ & $3 \cdot 27$ & 2 & 14 \\
\hline
\end{tabular}

* Hyperuricaemia $=$ uric acid greater than $7.0 \mathrm{mg}$. per cent. in males and greater than $6.0 \mathrm{mg}$. per cent. in females.

From analysis of the data it was apparent that uric acid levels were higher in overweight individuals. Multiple regression analyses were performed to assess the relative contributions of age, sex, height, weight, and body surface to the total uric acid level. The uric acid was highly correlated with weight, and even more highly correlated with body surface. Whether this association is due to increased fat, increased muscle, previous dietary indiscretion, or other factors is not known. There was also a significant association of uric acid with sex but not with age. 
The regression equations are given in Table II. The uric acid of each individual was calculated by these equations and subtracted from the observed uric acid. This gave a uric acid value corrected for age, sex, and body surface; the characteristics of the distributions of corrected uric acid levels in Pima Indian males and females are given in Table III. The results in Blackfeet are similar. The means are zero and the standard deviations one. A slight positive skewness is present, the value being less than 0.5. A slight leptokurtosis is also present, the value being only slightly greater than the normal value of 3. However, the distributions are statistically consistent with the theoretically perfect normal curve when $\chi^{2}$ is used as a test of goodness of fit.

TABLE II

REGRESSION EQUATION OF URIC ACID ON AGE, SEX AND BODY SURFACE IN TWO POPULATIONS

Age (yrs); Sex (Male = 0, Female = 1); Body Surface (BS) (m.2)

\begin{tabular}{l|c|c}
\hline \multicolumn{1}{c|}{ Tribe } & $\begin{array}{c}\text { Number of } \\
\text { Persons }\end{array}$ & Regression Equation \\
\hline Blackfeet & 1,018 & UA $=2.25+\begin{array}{c}0.0038 \text { Age }- \\
0.41 \text { Sex }+1.42 \mathrm{BS}\end{array}$ \\
\hline Pima & 972 & UA $=3.07-\begin{array}{c}0.0027 \text { Age }- \\
0.57 \text { Sex }+0.84 \mathrm{BS}\end{array}$ \\
\hline
\end{tabular}

Regressions on sex and body surface are highly significant. Regression on age is not significant.

TABLE III

DISTRIBUTION OF CORRECTED* URIC ACID VALUES IN PIMA INDIANS, BY SEX

Mean $=0 ;$ Standard Deviation $=1$

\begin{tabular}{c|c|c|c|c|c}
\hline Sex & $\begin{array}{c}\text { Number } \\
\text { of } \\
\text { persons }\end{array}$ & Bimodality & $\begin{array}{c}\text { Skewness } \\
\pm \text { S.D. }\end{array}$ & $\begin{array}{c}\text { Kurtosis } \\
\pm \text { S.D. }\end{array}$ & $\begin{array}{c}\text { Probability } \\
\text { normally } \\
\text { distributed }\end{array}$ \\
\hline Male & 449 & No & $\begin{array}{c}+0 \cdot 31 \\
\pm 0.12\end{array}$ & $\begin{array}{c}3 \cdot 86 \\
\pm 0 \cdot 23\end{array}$ & $0 \cdot 14$ \\
\hline Female & 464 & No & $\begin{array}{c}+0 \cdot 42 \\
\pm 0.11\end{array}$ & $\begin{array}{c}3 \cdot 38 \\
\pm 0 \cdot 23\end{array}$ & 0.15 \\
\hline
\end{tabular}

* Corrected for age, sex, and body surface.

It is an accepted genetic principle that monogenic traits are inherently discontinuous-in other words either present or absent. If the distribution of corrected uric acid levels were bimodal, it would indicate that the trait might be discontinuous, and hence might be monogenic. Actually, there is no bimodality in the populations, and hyperuricaemia is a continuous trait-it is present in varying degrees. Hence, analysis of hyperuricaemia as a simple trait determined by a single gene is somewhat artificial. Nevertheless, such an analysis was made. Some familial aggregation was present-the trait did not fit a hypothesis of random distribution. Likewise the distribution was not consistent with recessive inheritance and the possibility of its being a simple dominant trait was ruled out since there were many instances of normal parents producing hyperu $₫$ ricaemic offspring.

The uric acid levels of relatives of hyperuricaemico individuals were determined. Although themeanurice acid of these individuals was $0.25 \mathrm{mg}$. per cent. highe than the population average, there was no suggestion? of bimodality in their distribution. This observation is in agreement with that of Hauge and Harvale (1955), who reported a normal distribution of urie acid levels in relatives of probands with hyperurio caemia. In view of the normal distribution of hyperuricaemia, both in the population as a whole and in relatives of hyperuricaemic probands, the trait, if a genetic one at all, would most likely be్ determined by several genes. Were this so, the phenotypic uric acid value of the parent should show a correlation with the value of the offspring $N$ From the magnitude of this correlation, it wouldo then be possible to estimate the heritability by the following formula $1 / 2 h^{2}=b_{o p}$, where $h^{2}$ is the heritability and $b_{o p}$ is the regression coefficient of offspring on parent. Perfect heritability would give $h^{2}=100$ per cent. (Falconer, 1960).

An illustration of a known polygenic trait in the Pima Indians is the abnormally short fifth middle phalanx seen in about 20 per cent. of these peoplese The degree of shortness varies quite widely; $\$ y$ P using the above formula-that of measuring magnitude of correlation between parent and chil we estimated its heritability at about 70 per cent:- $\frac{-5}{0}$ indicating that the trait is primarily genetic. The same analysis was then applied to uric acid levels of 281 Blackfeet and 303 Pima parent-child pairs, and the results are given in Table IV. The estimates of heritability were only 21.6 per cent. in the Blackfeet and 23.8 per cent. in the Pimas. This wouldo indicate a rather low heritability, which in turn suggests that the trait is for the most part not genetic one, but is instead largely determined bys environmental factors.

TABLE IV

ESTIMATES OF HERITABILITY

Based on Correlation of Corrected Uric Acid Levels of Parent and

\begin{tabular}{l|c|c|}
\hline \multicolumn{1}{|c|}{ Offibe } & $\begin{array}{c}\text { Number of } \\
\text { Parent-Child } \\
\text { Pairs }\end{array}$ & Heritability $\begin{array}{c}\text { Estimate of Standard Deviation } \\
\text { Blackfeet }\end{array}$ \\
Pima & 281 & $21 \cdot 61 \pm 6 \cdot 38 \%$ \\
\hline
\end{tabular}

There is, however, a small but definite relationship between the uric acid values corrected for age, sex and body surface of parents and offspring. Such $a^{+}$ correlation might conceivably be due to undetected 
common familial factors-such as common dietary habits-or, on the other hand, could be due to genetic transmission. If this be the case, it is probably polygenic and not due to a single dominant or recessive gene.

The final answer, however, should take into account certain peculiarities of transmission between the sexes which were noted in this study (see Table V). A very high rate of transmission from mother to daughter was observed in both populations, but the rates of transmission in the other sex combinations, such as father and son, etc., were lower and somewhat irregular. It is tempting, in view of these facts, to speculate that at least some of the genes involved are sex-linked dominants. There are so many environmental factors obscuring the possible inheritance, however, that any speculation about the presence or absence of a specific genetic mechanism is probably unwarranted at this time.

TABLE V

ESTIMATES OF HERITABILITY, BY SEX

\begin{tabular}{|c|c|c|c|}
\hline \multirow{2}{*}{ Parent } & \multirow{2}{*}{ Offspring } & \multicolumn{2}{|c|}{ Percentage Heritable } \\
\hline & & Blackfeet & Pima \\
\hline Father & $\begin{array}{l}\text { Son } \\
\text { Daughter }\end{array}$ & $\begin{array}{l}10 \cdot 04 \\
25 \cdot 23\end{array}$ & $\begin{array}{r}-15 \cdot 03 \\
15 \cdot 35\end{array}$ \\
\hline Mother & $\begin{array}{l}\text { Son } \\
\text { Daughter }\end{array}$ & $\begin{array}{r}0 \cdot 69 \\
44 \cdot 29\end{array}$ & $\begin{array}{l}19 \cdot 68 \\
56 \cdot 42\end{array}$ \\
\hline
\end{tabular}

\section{Summary}

Serum uric acid was determined with the uricase spectrophotometric method on 86 per cent. of Blackfeet and Pima Indians aged 30 and older living on their respective reservations, 7 per cent. of the Blackfeet and about 3 per cent. of the Pimas had hyperuricaemia. There was a definite positive association with obesity which was even more marked with body surface. Serum uric acid levels corrected for age, sex, and body surface gave values which were statistically consistent with a perfect normal distribution.

Some familial aggregations were present but the distribution was not consistent with simple recessive or dominant inheritance. Analysis as a polygenic trait indicated a rather low heritability, which suggests that the trait is for the most part not a genetic one but is instead largely determined by environmental factors.

\section{REFERENCES}

Falconer, D. S. (1960). "Introduction to Quantitative Genetics", p. 168. Oliver and Boyd, Edinburgh.

Hauge, M., and Harvald, B. (1955). Acta med. scand., क़ $152,247$.

Kellgren, J. H. (1962). Bull. rheum. Dis., 13, 291.

Liddle, R., Seegmiller, J. E., and Laster, L. (1959). J. Lab. clin. Med., 54, 903.

Smyth, C. J., Cotterman, C. W., and Freyberg, R. H. (1948). J. clin. Invest., 27, 749.

Stecher, R. H., Hersh, A. H., and Solomon, W. (1949.) Ann. intern. Med., 31, 595,

\section{La génétique de l'hyperuricémie chez les Indiens Blackfeet et Pima}

\section{RÉSUMÉ}

On détermina l'acide urique sérique par la méthode ô spectrophotométrique à l'uricase chez 86 pour cent des Indiens Blackfeet et Pima, âgés de 30 ans ou plus et $\overrightarrow{\vec{V}}$ habitant à leurs reservations respectives. Sept pour cent des Blackfeet et près de 3 pour cent des Pimas accusèrent $ㅇ$ de l'hyperuricémie. On nota un rapport direct bien déterminé entre l'uricémie et l'obésité, particulèrement $\bar{z}$ prononcé pour la surface du corps. Les valeurs de l'acide @ urique dans le sérum, ajustées selon l'âge, le sexe et la surface du corps, correspondèrent parfaitement à la distribution statistique normale.

On observa quelques agrégations familiales, mais leus distribution n'indiqua pas de simple hérédité, recessive ou dominante. L'analyse de ce phénomène polygénésique indiqua une hérédité bien faible, ce qui fait penser $\overline{\mathrm{T}}$. l'intervention des facteurs ambients plutôt que génétiquest:

La genética de la hiperuricemia en los indios Blackfeet y Pima

\section{SUMARIO}

Se determinó el ácido úrico sérico empleando la uricasa con el método espectrofotométrico en el 86 por ciento de los indios Blackfeet y Pima, de edad de 30 años o más, viviendo en sus reservaciones respectivas. El 7 por ciento de los Blackfeet y cerca de un 3 por ciento de los Pimas acusaron una hiperuricemia. Se notó una relación directa y bien determinada entre la uricemia y la obesidad, particularmente pronunciada al considerar la superficie del cuerpo. Las cifras del ácido úrico en el suero, ajustadas según el sexo, la edad y la superficie del cuerpo, correspondieron perfectamente a la distribución estadística normal.

Se vieron algunas agregaciones familiales, pero su distribución no indicó una herencia simple, recesiva o or dominante. El análisis de este fenómeno poligenético indica poca tendencia hereditaria y sugiere la intervención de factores ambientes más que genéticos. 